\title{
REDESAIN PONDOK PESANTREN DARUL HIJRAH PUTRI MARTAPURA
}

\author{
Umi Halisah Dina \\ Program Studi Teknik Arsitektur Fakultas Teknik Universitas Lambung Mangkurat \\ Dinaalisa57@gmail.com \\ Pakhri Anhar \\ Program Studi Teknik Arsitektur Fakultas Teknik Universitas Lambung Mangkurat \\ pakhrianhar@ulm.ac.id
}

\begin{abstract}
ABSTRAK
Pondok Pesantren Darul Hijrah Putri merupakan sebuah lembaga pendidikan islam khusus perempuan yang ada di Martapura Kalimantan Selatan dan telah berdiri sejak tahun 1995. Dengan waktu yang cukup lama selama lebih dari 20 tahun, pondok pesantren ini telah banyak mengalami perkembangan terutama dalam hal pembangunan, akan tetapi perkembangan pondok pesantren ke depan akan semakin kompleks mengingat adanya program usaha pemerintah yang ingin bekerja sama dengan dunia Pondok Pesantren dalam hal ekonomi kreatif, hal ini dimaksudkan untuk mengembangkan ekonomi dan Sumber Daya Manusia (SDM) dalam lingkungan pondok pesantren. Maka dari itu pengembangan ekonomi kreatif sebagai media pembelajaran perlu dimasukkan untuk mempertahankan eksistensi pondok pesantren ini dimasa yang akan datang. Metode yang dipakai pada penulisan ini adalah metode programming yang mana mempunyai 2 langkah utama yaitu: Programming yang merupakan upaya penelusuran masalah dan; Schematic Design; upaya pemecahan masalah yang didapat. Hasil dari metode yang dipakai akhirnya didapatlah Konsep islamic creative educative place yang mana ia merupakan kombinasi dari 2 variabel utama yaitu islamic education dan creative education.

Kata kunci: pondok pesantren, ekonomi kreatif, islamic creative educative
\end{abstract}

\begin{abstract}
Darul Hijrah Islamic Boarding School for females is a women's Islamic education institution in Martapura South Kalimantan and has been established since 1995. With a long time of more than 20 years, this boarding school has experienced many developments, especially in terms of development, but the development of Islamic boarding schools in the future will be increasingly complex considering the existence of government business programs that want to cooperate with the world of Islamic Boarding Schools in terms of the creative economy, this is intended to develop the economy and Human Resources (HR) within the boarding school environment. So from that the development of the creative economy as a learning media needs to be included to maintain the existence of this boarding school in the future. The method that was used in this report is a programming method which has two main steps: a) Programming which is a problem-tracking and; b) Schematic Design; a problem solving. The results of the method used finally got the Islamic creative educative place concept which is a combination of the two main variables namely Islamic education and creative education
\end{abstract}

Keyword: Islamic boarding school, creative economy, Islamic creative educative

\section{PENDAHULUAN}

Sekolah merupakan sebuah wadah atau tempat belajar murid yang berada dibawah pengawasan guru yang bertujuan untuk meningkatkan kualitas Sumber Daya Manusia agar terbentuk sebuah sikap dan moral yang lebih baik. Dalam praktiknya saat ini sebuah 
sekolah terutama yang berbasis keagamaan sangat dibutuhkan di tengah-tengah masyarakat. Hal ini dikarenakan pendidikan yang berbasis keagamaan diharapkan dapat membentuk manusia yang ber-Akhlaqul Karimah serta mempunyai moral yang baik dan harapan nantinya dapat menjadi panutan dalam kehidupan bermasyarakat. Saat ini sekolah berbasis keagamaan sebagian besar banyak dibuka oleh yayasan swasta, yang mana sekolah tersebut diberi label islam di belakangnya seperti misalnya SDIT, SMPIT, SMAIT, Islamic Boarding School, serta Pondok Pesantren.

Pondok Pesantren sebagai lembaga pendidikan islam tertua di Indonesia telah memberikan kontribusi nyata di dalam pengembangan dakwah pendidikan islam di indonesia, Menurut Imam Zarkasyi (1996), mengartikan pesantren sebagai lembaga pendidikan islam dengan sistem asrama atau pondok, dimana Kyai sebagai figur sentralnya, masjid sebagai pusat kegiatan yang menjiwainya, dan pengajaran agama islam di bawah bimbingan kyai yang diikuti santri sebagai kegiatan utamanya. Secara singkat pesantren juga dikatakan sebagai laboratorium kehidupan bersifat mikro tempat santri belajar kehidupan bermasyarakat dalam berbagai segi dan aspeknya.

Di Kalimantan Selatan saat ini telah tercatat terdapat 240 Pondok Pesantren yang tersebar di 13 Kabupaten/Kota seperti yang tertera di tabel berikut:

Tabel 1. Data Pondok Pesantren di Kalimantan

\begin{tabular}{|l|l|l|}
\hline \multicolumn{2}{|c|}{ Selatan } \\
\hline 1 & \multicolumn{1}{|c|}{ Kabupaten/kota } & \multicolumn{1}{c|}{$\begin{array}{c}\text { Jumlah Pondok } \\
\text { Pesantren }\end{array}$} \\
\hline 2 & Bulu Sungai Selatan & 22 buah \\
\hline 3 & Tabalong & 15 buah \\
\hline 4 & Hulu Sungai Tengah & 11 buah \\
\hline 5 & Balangan & 23 buah \\
\hline 6 & Banjar & 9 buah \\
\hline 7 & Batola & 39 buah \\
\hline 8 & Banjarmasin & 18 buah \\
\hline 9 & Hulu Sungai Utara & 27 buah \\
\hline
\end{tabular}

\begin{tabular}{|l|l|l|}
\hline 10 & Tapin & 15 buah \\
\hline 11 & Kotabaru & 16 buah \\
\hline 12 & Tanah Laut & 23 buah \\
\hline 13 & Tanah Bumbu & 14 buah \\
\hline Jumlah & $\mathbf{2 4 0}$ buah \\
\hline $\begin{array}{l}\text { (Sumber:kalsel.kemenag.go.id, } \\
\text { Pesantren) }\end{array}$
\end{tabular}

Dari tabel diatas terhitung ada 39 buah Pondok Pesantren yang berdomisili di Kabupaten Banjar salah satunya yaitu Pondok Pesantren Darul Hijrah Putri di Desa Batung Cindai Alus Martapura. Pondok ini didirikan sejak tahun 1995 oleh KH Gazali Mukhtar dan merupakan Pondok Pesantren berbasis Modern yang meniru dari Pondok Almamaternya, yaitu Pondok Modern Darussalam Gontor Ponorogo, dengan dua tingkat pendidikan yaitu SMP Darul Hijrah Putri dan SMA Darul Hijrah Putri pada awal berdirinya.

Dengan waktu yang cukup lama selama lebih dari 20 tahun, eksistensi Pondok Pesantren Darul Hijrah Putri pun semakin bertambah pesat sebagai salah satu Pondok Pesantren Modern khusus putri yang ada di Martapura Kalimantan Selatan, dalam hal ini populasi santriwati yang ada didalamnya pun mulai berkembang pesat, perkembangan tentang banyaknya santriwati dapat dilihat dari tabel jumlah santriwati dari tahun ke tahun dibawah ini:

Tabel 2. Data siswa \& Santriwati PPDHP 5 Tahun Terakhir

\begin{tabular}{|c|c|c|c|}
\hline No & Tahun Ajaran & \multicolumn{2}{|c|}{ Jumlah Santriwati } \\
\hline \multirow[t]{3}{*}{1} & \multirow[t]{3}{*}{ TA 2014/2015 } & SMP & 960 \\
\hline & & SMA & 535 \\
\hline & & Total & 1495 \\
\hline \multirow[t]{3}{*}{2} & \multirow[t]{3}{*}{ TA 2015/2016 } & SMP & 981 \\
\hline & & SMA & 635 \\
\hline & & Total & 1616 \\
\hline \multirow[t]{3}{*}{3} & \multirow[t]{3}{*}{ TA 2016/2017 } & SMP & 980 \\
\hline & & SMA & 680 \\
\hline & & Total & 1660 \\
\hline \multirow[t]{4}{*}{4} & \multirow{4}{*}{ TA 2017/2018 } & SD & 49 \\
\hline & & SMP & 930 \\
\hline & & SMA & 743 \\
\hline & & Total & 1722 \\
\hline \multirow[t]{4}{*}{5} & \multirow[t]{4}{*}{ TA 2018/2019 } & SD & 78 \\
\hline & & SMP & 916 \\
\hline & & SMA & 817 \\
\hline & & Total & 1861 \\
\hline
\end{tabular}


(sumber: data hasil wawancara pribadi)

Dari tabel diatas dapat dilihat bahwa semakin tahun pertumbuhan santriwati semakin bertambah, hal ini membuktikan bahwa minat masyarakat terhadap Pondok Pesantren Darul Hijrah Putri semakin bertambah tahun demi tahun, ditambah juga dengan adanya pembukaan sekolah tingkat dasar yaitu SD-IBS baru dikawasan tersebut. Dengan adanya hal ini mengakibatkan pertumbuhan fasilitas-fasilitas yang dibutuhkan di dalam Pondok harus berimbang sejalan dengan populasi santriwati didalamnya, terutama dalam hal pembangunan. Akibatnya pembangunan fasilitas Pondok saat ini dibangun dengan cara berangsur-angsur sesuai dengan kebutuhan santriwati di dalamnya tanpa melewati proses perencanaan panjang di awal, sehingga menyebabkan kawasan yang kurang asri dan nyaman baik dilihat secara visual dan saat di tempati, hal ini tentu tidak sejalan dengan misi pondok pesantren dalam hal menyelenggarakan lembaga pendidikan islam yang bermutu, profesional, berkeseimbangan, asri, sejahtera.

Selain hal itu, perkembangan Pondok Pesantren ke depan akan semakin komplek mengingat adanya program usaha pemerintah yang ingin bekerja sama dengan dunia Pondok Pesantren dalam hal ekonomi kreatif untuk mengembangkan ekonomi dan Sumber Daya Manusia (SDM), sehingga dengan hal ini diharapkan dapat menumbuhkan potensi para santri di pondok pesantren menjadi lebih kreatif dan mandiri kedepannya, serta dapat menjadi aset untuk kemajuan negara di masa depan.

Dari kesimpulan diatas, maka kawasan Pondok Pesantren Darul Hijrah Putri perlu dilakukan perancangan ulang atau redesain sebagai respon permasalahan tersebut. Hal ini dapat dituangkan dengan cara mengatur zonasi kawasan dalam pondok baik dalam hal tata massa serta tata ruang agar menciptakan suasana pondok yang lebih edukatif dan nyaman lagi, serta penambahan kebutuhan di masa depan yang dapat menunjang dalam hal ekonomi kreatif sebagai nilai jual pondok pesantren.

\section{PERMASALAHAN}

Berdasarkan uraian dalam latar belakang diatas maka permasalahan arsitektur yang diangkat dalam judul ini adalah Bagaimana merancang kembali kawasan Pondok Pesantren Modern Darul Hijrah Putri sebagai Lembaga Pendidikan Islam yang mendukung dalam hal ekonomi kreatif pondok?

Pada kasus Redesain kawasan Pondok Pesantren Modern Darul Hijrah Putri ini perancangan dibatasi hanya dilakukan untuk tingkat SMP dan SMA, difokuskan pada perancangan ruang belajar mengajar pondok, asrama, masjid dan area pendukung lainnya yang disesuaikan untuk menjawab permasalahan yang diangkat.

\section{TINJAUAN PUSTAKA}

\section{A. Pengertian Pondok Pesantren}

Pondok pesantren pada dasarnya diambil dari 2 suku kata yaitu Pondok dan juga Pesantren, pondok diambil dari kata funduk yang mana ia berasal dari bahasa arab artinya asrama atau hotel dan berfungsi sebagai tempat tinggal, sedangkan pesantren diambil dari kata santri dengan pemberian imbuhan pe- di awal kata dan imbuhan -an di akhir kata, kata santri diambil dari bahasa sansekerta "cantrik" yang berarti orang yang selalu mengikuti guru.

\section{B. Unsur Unsur Pondok Pesantren}

Pondok Pesantren adalah sebuah lembaga pendidikan yang memiliki ciri khas tertentu di dalamnya, unsur-unsur inilah yang membedakannya dengan lembaga-lembaga pendidikan yang lain. menurut Zamakhsyari Dhofier ia menyebutkan ada lima elemen utama pesantren yaitu pondok, masjid, santri, kyai, dan pengajaran kitab-kitab klasik.

\section{KEHIDUPAN PONDOK PESANTREN}

Dalam kehidupan Pondok Pesantren terutama Pondok Pesantren Modern pada dasarnya yang terpenting bukan dalam hal pelajaran saja, melainkan aspek kehidupan sehari harinya juga diperhatikan dikarenakan ia beraktivitas di dalam ruang lingkup yang sama selama 24 jam penuh, sebagian besar Pondok Pesantren Modern kebanyakan 
mewajibkan para santrinya untuk tinggal di dalam pondok atau mondok, hal ini dikarenakan untuk memudahkan kontrol kyai maupun pengurus pondok terhadap para santrinya serta untuk membatasi para santri dari pengaruh dunia luar, sehingga dalam proses pembelajaran dapat berlangsung efektif. secara kasat mata Pondok Pesantren sebagian besar mempunyai ruang lingkup yang terpisah dari lingkungan sekitarnya yang mana hal ini dilakukan dengan dasar yang jelas, yaitu pembentukan karakter dan pola terlebih dahulu sebelum akhirnya terjun ke masyarakat, dengan hal ini maka biasanya di dalam Pondok Pesantren diberi fasilitas fasilitas yang sesuai dengan kebutuhan aktivitasnya. Hal-hal lainnya yang tidak kalah penting diantaranya dalam pembentukan karakter santriwati adalah penanaman akhlak dan tingkah laku yang baik, kesederhanaan, kedisiplinan, kemandirian, sikap gotong royong, ukhuwah islamiyah dan juga kebersamaan.

Selain itu, dalam berkomunikasi, saat ini di Pondok Pesantren Modern juga diatur dengan cara mewajibkan seluruh santri, kyai maupun pengurus pondok lainnya dalam menggunakan 2 bahasa internasional yaitu bahasa arab dan inggris, hal ini terjadi secara tidak langsung mengacu pada Pondok Modern Gontor yang mempelopori pondok-pondok Modern di Indonesia, pada awalnya aturan ini berlaku untuk Pondok Gontor Pusat dan cabang serta juga pondok-pondok alumni, namun seiring berkembangnya zaman, sistem ini juga dianut oleh banyak pondok Modern di Indonesia, dikarenakan aturan tersebut berbuah positif yang dampaknya para santri dapat mengimbangi kemajuan di luar pondok tanpa harus tertinggal di belakang, selain itu hal ini juga berguna dalam pembentukkan cikal bakal alumni yang intelek.

\section{TINJAUAN EKONOMI KREATIF}

Saat ini, bisnis ekonomi kreatif di Indonesia banyak dikembangkan oleh anak-anak muda, hal ini dikarenakan anak muda mengedepankan inovasi dan kreativitasan dalam melakukan suatu kegiatan, dari hal ini pula akhirnya membuat
Pemerintah Indonesia mulai menjangkau kalangan santri santri di pondok pesantren dalam mengembangkan ekonomi kreatif sebagai aset SDM di masa depan, sehingga pada tahun 2018 pemerintah mulai mencanangkan program ekonomi kreatif berbasis pondok pesantren, hal ini diharapkan nantinya dapat menciptakan santri yang tidak hanya agamis namun juga memiliki jiwa entrepreneur, mandiri dan terampil, sehingga mereka dapat mengembangkan keterampilan yang telah didapat menjadi sebuah lapangan usaha, baik bagi dirinya sendiri maupun orang lain. Selain itu program ekonomi kreatif berbasis pesantren juga dibuat agar menciptakan kemandirian pesantren dengan cara mengangkat potensi khas dari masing masing daerah yang bisa diangkat dengan peran para santri dalam mengembangkan ekonominya.

Saat ini di pondok pesantren darul hijrah puteri setidaknya ada beberapa macam ekonomi kreatif yang dapat dikembangkan salah satunya yaitu seperti ekonomi kreatif di bidang pertanian dan juga perkebunan, dimana pondok dijadikan sebagai kawasan kebun dan juga menjadi kawasan pendidikan.

lingkup ekonomi kreatif dalam bidang pertanian yang dapat diangkat di pondok pesantren darul hijrah putri antara lain:

- kebun dan taman buah dan sayur

- rumah hidroponik

- market

- kerajinan tangan dari hasil maupun limbah pertanian

- workshop kegiatan

- pengembangan produk

\section{TINJAUAN TERHADAP PONDOK PESANTREN DARUL HIJRAH}

Darul hijrah Diambil dari dua kata bahasa arab yaitu "darul" atau "daar" dan "hijrah" yang jika digabung mempunyai arti sebagai sebuah tempat berhijrah. Darul Hijrah merupakan sebuah nama Pondok Pesantren yang terletak di cindai alus martapura Kabupaten Banjar dengan tipe pesantren modern mengikuti pondok almamaternya yaitu Pondok Modern Darussalam Gontor Ponorogo. Saat ini pondok darul hijrah telah 
berdiri di 3 tempat,1 untuk Putri yaitu di desa batung cindai alus martapura, sedangkan 2 lainnya merupakan pondok khusus putra yang berada di cindai alus martapura dan trikora banjarbaru.

\section{E. KURIKULUM PONDOK PESANTREN DARUL HIJRAH PUTRI}

Kurikulum pendidikan di Pondok Pesantren Darul Hijrah Putri terdiri dari 2 kurikulum, yaitu kurikulum pendidikan nasional yang sudah diatur untuk sekolah-sekolah di indonesia (Kemendikbud), dan juga kurikulum gontor. Hal ini dikarenakan pendidikan di Pondok Darul Hijrah merupakan perpaduan antara Pendidikan Nasional dan Pendidikan Pondok Pesantren, kurikulum negeri dipakai dalam proses belajar mengajar dalam jenjang pendidikan SMP dan juga SMA. Sedangkan kurikulum gontor dipakai dalam 24 jam kehidupan mereka di pondok tersebut, bukan hanya dalam proses belajar mengajar saja namun juga dalam kehidupan sehari harinya, dalam hal ini maka kurikulum yang diambil dari gontor merupakan kurikulum yang mendominasi kehidupan mereka.

Dalam proses belajar mengajar pemakaian Kurikulum Gontor di pondok ini dinamakan Tarbiyatul Muallimatul Islamiyyah (TMI) dengan 2 program yaitu program reguler dan martikulasi. program reguler dipakai untuk lulusan Sekolah Dasar atau setara yang ingin belajar di pondok dengan kurun waktu 3 tahun ataupun 6 tahun, sedangkan program matrikulasi dipakai untuk lulusan Sekolah Menengah Pertama atau setara yang ingin belajar di pondok dengan penambahan 1 tahun di awal sebagai bentuk penyetaraan, sehingga di tipe matrikulasi ini santriwati menempuh pendidikan SMA selama 4 tahun lamanya.

Tabel 5. Perbandingan Mata Pelajaran pada 2 Kurikulum

\begin{tabular}{|l|l|}
\hline \multicolumn{1}{|c|}{$\begin{array}{c}\text { Kurikulum Pondok } \\
\text { Pesantren }\end{array}$} & Kurikulum pendidikan umum \\
\hline Durusul Lughoh & Matematika \\
\hline Tarikh Islam & Bahasa Indonesia \\
\hline Mutholla'ah & Bahasa Inggris \\
\hline Mahfudzot & IPA \\
\hline
\end{tabular}

\begin{tabular}{|l|l|}
\hline Khat & IPS \\
\hline Al-Qur'an & Bahasa Arab \\
\hline Fiqh & TIK \\
\hline Ushul Fiqh & Sejarah \\
\hline Tafsir & Ekonomi \\
\hline Nahwu & Geografi \\
\hline Shorof & Sosiologi \\
\hline Imla & Fisika \\
\hline Tajwid & Biologi \\
\hline Tarbiyah & Kimia \\
\hline Mustholahul Hadist & Pendidikan kewarganegaraan \\
\hline Faraid & Seni budaya \\
\hline Qiraatul Kutub & Agama Islam \\
\hline Insya & \\
\hline Tauhid & \\
\hline Grammar & \\
\hline Conversation & \\
\hline Hadist & \\
\hline Ushuluddin & \\
\hline Nisaiyyah & \\
\hline Sumber & \\
\hline
\end{tabular}

(sumber: data hasli wawancara pribadi)

Untuk kehidupan sehari harinya pada kurikulum ini juga diterapkan pada kehidupan mereka sehari harinya diantaranya yaitu penggunaan bahasa arab dan bahasa inggris sebagai bahasa pergaulan dan bahasa pengantar pendidikan, kecuali pada beberapa mata pelajaran yang memang disampaikan dengan bahasa indonesia. Penggunaan bahasa arab dimaksudkan agar para santriwati memiliki dasar dasar yang kuat dalam pembelajaran pelajaran islam sedangkan bahasa inggris dipakai karena merupakan bahasa internasional yang sangat penting dikuasai pada zaman sekarang.

\section{F. KEHIDUPAN PONDOK PESANTREN DARUL HIJRAH PUTRI}

Kehidupan di pondok pesantren darul hijrah putri dilaksanakan 24 jam penuh, dengan jam aktif kegiatan dimulai dari pukul 04.00 wita hingga pukul 23.00 wita setiap harinya. Hal ini dapat dilihat dari tabel-tabel yang ada di bawah ini:

Tabel 6. Jadwal Kegiatan Harian Santriwati 


\begin{tabular}{|c|c|c|}
\hline $\begin{array}{c}\text { Jam } \\
\text { operasional }\end{array}$ & Kegiatan & Tempat \\
\hline $04.00-05.00$ & Bangun pagi,MCK & Asrama \\
\hline $05.00-06.00$ & Sholat subuh & Masjid \\
\hline $06.00-06.15$ & Pembagian kosa kata & Area pondok \\
\hline $06.15-07.00$ & Sarapan/MCK & $\begin{array}{l}\text { Ruang } \\
\text { makan.asrama }\end{array}$ \\
\hline $07.30-09.30$ & Masuk kelas sesi 1 & Area kelas \\
\hline $09.30-10.00$ & Istirahat 1 & Kantin,koperasi \\
\hline $10.00-12.30$ & Masuk kelas sesi 2 & Area kelas \\
\hline $12.30-13.00$ & Sholat zuhur & Masjid \\
\hline $13.00-13.50$ & Makan siang.dll & Ruang makan \\
\hline $14.00-15.30$ & Masuk kelas sesi 3 & Area kelas \\
\hline $15.30-06.10$ & Sholat ashar & Masjid \\
\hline $16.10-06-00$ & 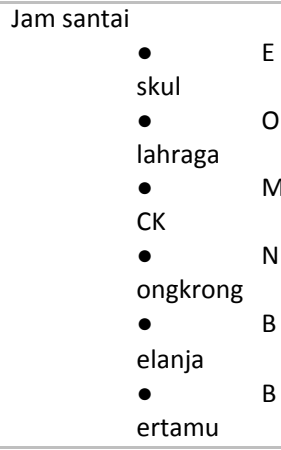 & $\begin{array}{l}\text { Lapangan } \\
\text { Lapangan } \\
\text { Asrama } \\
\text { Area pondok } \\
\text { Kantin,koperasi } \\
\text { Area tamu }\end{array}$ \\
\hline $06-00-06.20$ & Baca qur'an & Masjid \\
\hline $06.20-07.05$ & Sholat magrib & Masjid \\
\hline $07.05-07.45$ & Makan malam & Ruang makan \\
\hline $07.45-20.15$ & Sholat isya & Masjid \\
\hline $20.15-22.00$ & Belajar malam & $\begin{array}{l}\text { Area pondok kecuali } \\
\text { area tamu }\end{array}$ \\
\hline $22.00-22.30$ & $\begin{array}{l}\text { Persiapan tidur } \\
\text { malam }\end{array}$ & Asrama \\
\hline $22.30-22.45$ & Pengabsenan & Kamar tidur \\
\hline 22.45-subuh & Tidur & Kamar tidur \\
\hline
\end{tabular}

Tabel 7. Jadwal Kegiatan Mingguan Santriwati

\begin{tabular}{|c|c|c|}
\hline $\begin{array}{c}\text { Waktu } \\
\text { pelaksanaan }\end{array}$ & Kegiatan & $\begin{array}{c}\text { Tempat } \\
\text { pelaksanaan }\end{array}$ \\
\hline Pagi minggu & Percakapan b.inggris & Lapangan utama \\
\hline Pagi minggu & Lari pagi & Sekitar pondok \\
\hline Pagi minggu & Kebersihan Umum & Area pondok \\
\hline Senin malam & $\begin{array}{l}\text { Pidato } b \text { inggris, } b \text { indo, } b \\
\text { arab }\end{array}$ & Area kelas \\
\hline Rabu pagi & Percakapan b.arab & Lapangan utama \\
\hline Kamis sore & Kebersihan Umim & Area pondok \\
\hline Jumat malam & $\begin{array}{l}\text { Pidato } b \text { inggris, } b \text { indo,b } \\
\text { arab }\end{array}$ & Area kelas \\
\hline Jumat sore & Pramuka & Lapangan utama \\
\hline
\end{tabular}

(sumber: data hasil wawancara pribadi)

Pada kegiatan-kegiatan diatas para santriwati dibimbing dan diawasi oleh pengurus pondok secara langsung, pengurus utama Pondok Pesantren diambil dari para santriwati senior tingkat kelas 5 atau setara dengan kelas 2 SMA dan dibawah bimbingan ustadzl ustadzah maupun pengasuhan santriwati. Pengurus pondok ini dibuat dalam bentuk organisasi yang didalamnya dibagi atas bermacam-macam bagian yang akan mereka urus dalam 24 jam dan menjadi tanggung jawab mereka, hal ini dimaksud untuk melatih para santriwati dalam berorganisasi dan mengurus kegiatan dalam skala besar seta membiasakan mereka dalam belajar bertanggung jawab.

Selain hal hal diatas, Pondok Darul Hijrah Putri juga mempunyai berapa kegiatan yang wajib dilakukan setiap tahunnya, kegiatan ini biasa diadakan di dalam area pondok, hal ini dapat dilihat pada tabel dibawah ini:

Tabel 8. Jadwal Kegiatan Wajib Tahunan

\begin{tabular}{|l|l|}
\hline \multicolumn{1}{|c|}{ Nama acara } & \multicolumn{1}{|c|}{ Tempat pelaksanaan } \\
\hline Penyambutan santriwati baru & Masjid \\
\hline Apel tahunan & Lapangan besar \\
\hline Perkemahan Khutbatul arsy & Lapangan besar \\
\hline Api unggun akbar & Lapangan besar \\
\hline Kuliah kepondokan & Lapangan utama \\
\hline Batung cup & Area pondok \\
\hline Acara kartini & Lapangan utama \\
\hline Perayaan maulid nabi & Masjid \\
\hline Perayaan isra mi'raj & Masjid \\
\hline Perayaan tahun baru islam & Masjid \\
\hline Pelantikan pengurus OSDA & Lapangan/masjid \\
\hline Musyawarah kerja OSDA & Lapangan/masjid \\
\hline LPJ pengurus OSDA & Lapangan/masjid \\
\hline Idul adha & Masjid \\
\hline Qurban \& nyate bareng & Lapangan utama \\
\hline Visi misi \& Pemilu pengurus baru & Lapangan utama \\
\hline Upacara 17 agustus & Lapangan besar \\
\hline Drama contest & Lapangan utama \\
\hline Lomba pidato 3 bahasa & Lapangan utama \\
\hline Panggung gembira & Lapangan utama \\
\hline Ta'mir ramadhan & Masjid \\
\hline Khataman Qur'an & Masjid \\
\hline Kuliah etika sebelum liburan & Masjid \\
\hline Khataman akhir & Masjid/lapangan \\
\hline Tes amaliyah tadris (tes mengajar) & Area kelas+ bawah \\
\hline Class meeting & \\
\hline
\end{tabular}




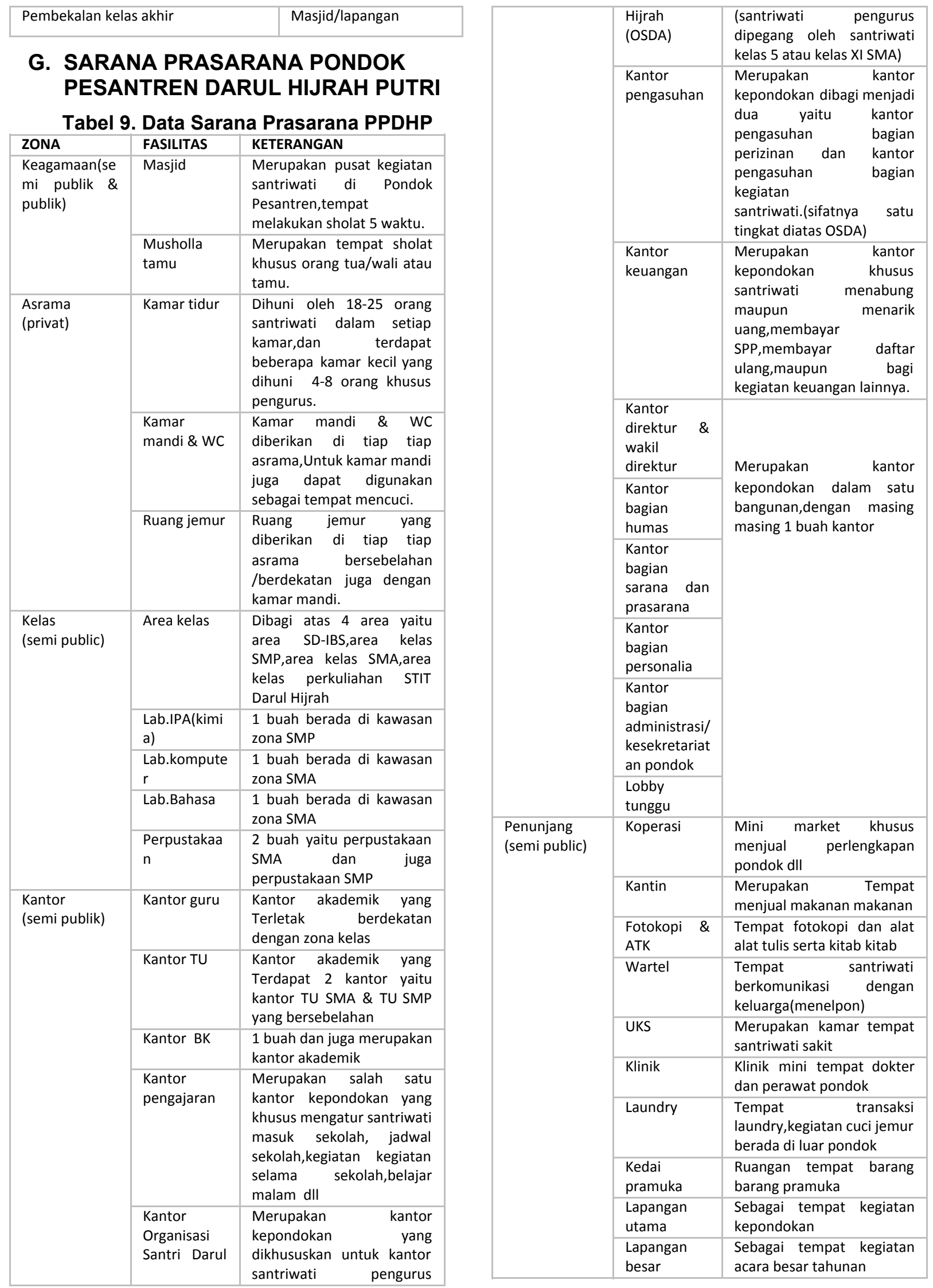




\begin{tabular}{|c|c|c|}
\hline & $\begin{array}{l}\text { Lapangan } \\
\text { olahraga }\end{array}$ & $\begin{array}{l}\text { Kegiatan olahraga dan } \\
\text { perlombaan }\end{array}$ \\
\hline & Aula & $\begin{array}{l}\text { Tempat berkumpul } \\
\text { santriwati }\end{array}$ \\
\hline \multirow[t]{6}{*}{ Servis } & Gudang & Gudang alat \\
\hline & $\begin{array}{l}\text { Ruang } \\
\text { makan }\end{array}$ & Tempat makan santriwati \\
\hline & $\begin{array}{l}\text { Dapur } \quad+ \\
\text { kamar acil } \\
\text { dapur }\end{array}$ & $\begin{array}{l}\text { Tempat penyiapan } \\
\text { makanan }\end{array}$ \\
\hline & Powerhouse & $\begin{array}{l}\text { Ruang genset,ruang } \mathrm{MCB} \\
\text { pusat,ruang pompa }\end{array}$ \\
\hline & Pos satpam & $\begin{array}{l}\text { Terdiri } 3 \text { pos,1 pos di } \\
\text { gerbang utama,1 pos di } \\
\text { dekat resepsionis,dan } 1 \text { pos } \\
\text { di gerbang } \\
\text { belakang/gerbang servis. }\end{array}$ \\
\hline & Ruang CS & $\begin{array}{l}\text { Ruang tempat para } \\
\text { cleaning servis istirahat }\end{array}$ \\
\hline \multirow[t]{3}{*}{ Publik } & Wisma tamu & Tempat tamu menginap \\
\hline & Parkir & \\
\hline & Resepsionis & $\begin{array}{l}\text { Tempat pemanggilan } \\
\text { santriwati khusus tamu }\end{array}$ \\
\hline
\end{tabular}

(sumber: data hasli wawancara pribadi)

\section{H. KEGIATAN EKSTRAKULIKULER SANTRIWATI}

Tabel 10. Data Ekstrakulikuler Santriwati PPDHP

\begin{tabular}{|c|c|}
\hline Nama Ekstrakulikuler & Tempat Pelaksanaan \\
\hline Paskibra & Lapangan \\
\hline Pasukan khusus pramuka & Lapangan \\
\hline Pasukan obor pramuka & Lapangan \\
\hline Karate & Lapangan \\
\hline Silat PSHT & Lapangan \\
\hline Tapak suci & Lapangan \\
\hline Karya IImiah Remaja & Ruangan indoor \\
\hline Kaligraphy & Ruangan indoor \\
\hline Drama & Ruangan indoor \\
\hline Marching Band & Lapangan \\
\hline Tahfidz Qur'an & Masjid \\
\hline Menari & Ruangan indoor \\
\hline Basket & Lapangan basket \\
\hline Volly & Lapangan volly \\
\hline Tenis meja & Ruang tenis meja \\
\hline Bulu tangkis & Langan bulu tangkis \\
\hline Nasyid & Ruangan indoor \\
\hline Tilawah Qur'an & Masjid \\
\hline Pidato 3 Bahasa & Ruang kelas \\
\hline Muhadhasah/ conversation & Lapangan \\
\hline Pramuka & Lapangan/ kedai pramuka \\
\hline
\end{tabular}

(sumber: data hasli wawancara pribadi)

\section{PEMBAHASAN}

\section{A. KONSEP PROGRAMATIK}

fokus tujuan rancangan pada kasus redesain ini adalah penataan kawasan pondok pesantren sebagai kawasan pendidikan yang dibuat sebaik mungkin dan sesuai dengan visi dan misi pondok, hal ini pastinya ditujukan lebih utama untuk kehidupan santriwati di dalamnya, selain itu juga diberikan penambahan fungsi baru sebagai nilai eksistensi pondok dimasa yang akan datang berupa pengembangan ekonomi kreatif dalam bidang pertanian dan perkebunan di kawasan pondok, hal ini dibuat atas 4 pertimbangan positif yaitu:

a) Perekonomian pondok yang meningkat

b) Kemandirian, ilmu dan kreatifitas santri meningkat

c) Meningkatkan kesejahteraan masyarakat

d) Sebagai ladang keikhlasan pondok terhadap pihak lain

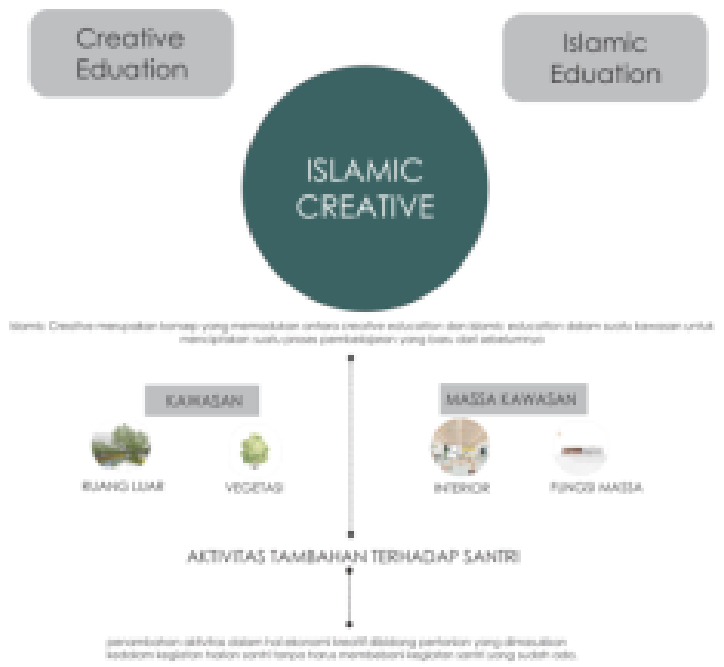

Gambar 1. Konsep Rancangan

islamic cretive dibuat dari dua poin utama yaitu pondok pesantren sebagai lembaga pendidikan islam dan pondok pesantren sebagai lembaga pendidikan yang bersifat kreatif, kreatif disini dimaknakan sebagai pondok yang bergerak dibidang ekonomi kreatif yang nantinya akan dimasukkan kedalam aktivitas kegiatan santriwati, sehingga hal ini mampu menciptakan suasana yang baru serta beda 
dari sebelumnya, Dari sinilah akhirnya diterapkan konsep islamic creative pada kawasan pondok yang didapat dari penggabungan 2 variabel sebelumnya. Penerapan konsep ini kemudian diterapkan ke dalam 2 aspek utama yaitu aspek kawasan dan aspek massa kawasan.

\section{B. PENERAPAN KONSEP TATA MASSA}

pada prinsip penyusunan tata massa disimpulkan dapat menggunakan 2 alternatif organisasi, yaitu organisasi linear dan organisasi radial. Dari 2 alternatif tersebut dipilihlah pola organisasi linier yang dianggap paling efisien terhadap kawasan, hal ini dikarenakan pada pola organisasi linear ia bisa mengekspresikan pergerakan suatu arah, mengorganisir bentuk-bentuk lain di sepanjang jalurnya, dan dapat dibungkus/ dibuat mengelilingi dalam satu ruang/ kawasan.

Tata massa/ zoning pada kawasan pondok pesantren darul hijrah Putri dibagi dalam 3 bagian yaitu zona publik, zona semi publik dan juga zona privat. Hal ini menyesuaikan dengan sifat dan kebutuhan ruang yang ada di dalam kawasan tersebut dengan dibuat seefektif mungkin. Hal ini dapat dilihat dari gambar dibawah ini:

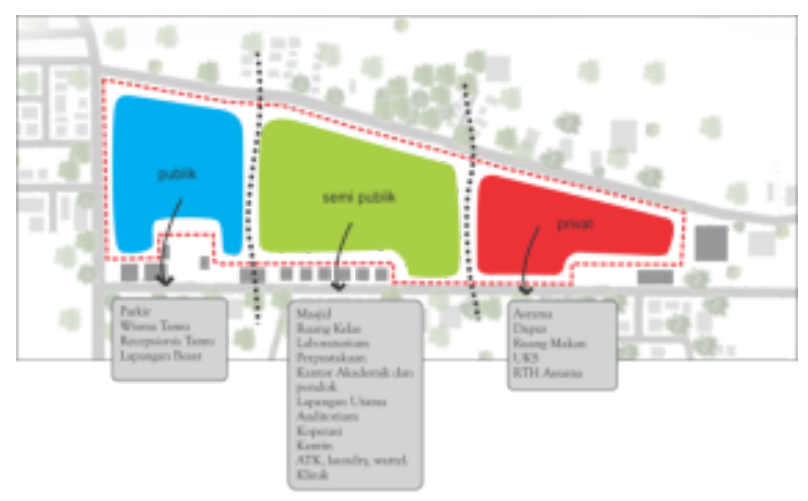

Gambar 2. Konsep Tata Massa

\section{PENERAPAN KONSEP RUANG}

\section{Konsep ruang kelas}

Dalam proses belajar di Pondok Pesantren Darul Hijrah Putri , mata pelajaran dibagi menjadi 2 bagian besar yaitu mata pelajaran pondok dan juga mata pelajaran umum, dengan porsi mata pelajaran pondok lebih besar dibanding mata pelajaran umum, maka mata pelajaran dikelompokkan menjadi beberapa bagian sesuai sifatnya, hal ini dibuat untuk menemukan suasana kelas yang sesuai dengan kegiatan didalamnya:

\section{- Mata Pelajaran Umum}

Mata pelajaran umum merupakan mata pelajaran yang diambil dari kurikulum pemerintah, dalam kasus ini mata pelajaran ini cenderung bersifat ceramah (penyampaian teori dsb), praktik kegiatan , kuis dan diskusi, maka dari semua mata pelajaran ia cenderung membutuhkan ruang untuk mendukung kegiatan tersebut, mata pelajaran yang masuk dalam kategori ini yaitu: matematika, b.Indonesia, IPA, biologi, fisika, kimia, sosiologi, geografi, ekonomi,PKn dll.

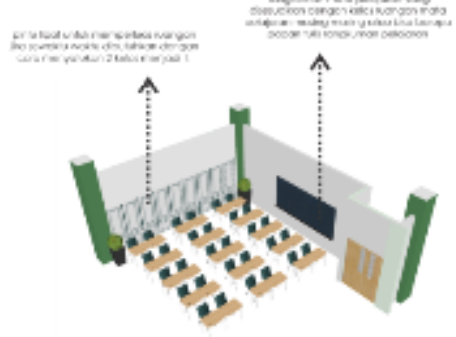

Gambar 3. Konsep Ruang Kelas Mata Pelajaran Umum

\section{- Mata Pelajaran bersifat Praktik, Ceramah serta Diskusi}

Mata Pelajaran Praktik, Ceramah dan Diskusi merupakan salah sifat dari mata pelajaran kepondokan, mata pelajaran ini cenderung mempunyai kegiatan ceramah yang dibarengi dengan diskusi di awal antara pengajar dan santriwati, namun dengan porsi diskusi yang lebih banyak dibanding ceramah, dan di awal yang kemudian disusul dengan praktik, praktik yang diberikan bisa bersifat tulis, praktik baca dan juga praktek hafalan, sehingga ia cenderung membutuhkan ruang belajar khusus untuk mewadahi kegiatan tersebut, mata pelajaran yang masuk dalam kategori ini diantaranya yaitu: imla dan insya, al qur'an , tajwid, tafsir, mahfudzot, Nahwu dan qir'atil kutub, durushul lughah / bahasa arab dan khat / kalighraphy. 


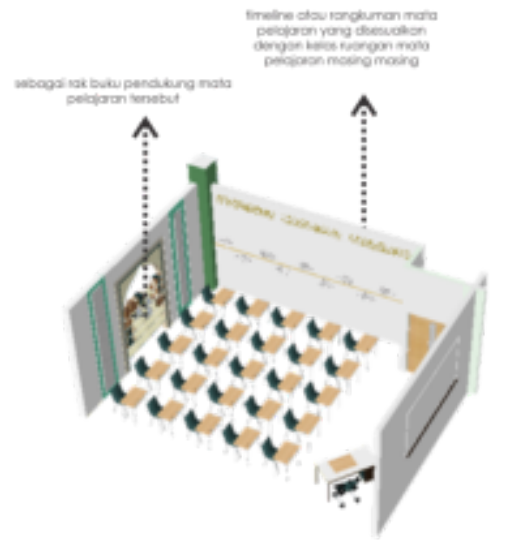

Gambar 4. Konsep Ruang Kelas Mata Pelajaran Praktik, Ceramah dan Diskusi

\section{- Mata Pelajaran bersifat Ceramah dan} Diskusi

Mata Pelajaran bersifat Ceramah merupakan sifat yang kedua dari mata pelajaran kepondokan, mata pelajaran ini cenderung mempunyai kegiatan utama ceramah dan sedikit diskusi pada praktiknya, santriwati secara umum hanya dituntut untuk memahami mengingat,dan mencatat apa isi dari materi yang telah disampaikan oleh pengajar, pada akhir sesi belajar biasanya para santri diberikan kuis bergilir untuk mengetes pemahaman terhadap isi materi yang telah disampaikan, mata pelajaran yang masuk dalam kategori ini diantaranya yaitu: fiqh, usuld fiqh, hadist, mushtolahul hadist, tarbiyah, faraid, tauhid, ushuluddin, dan tarikh islam

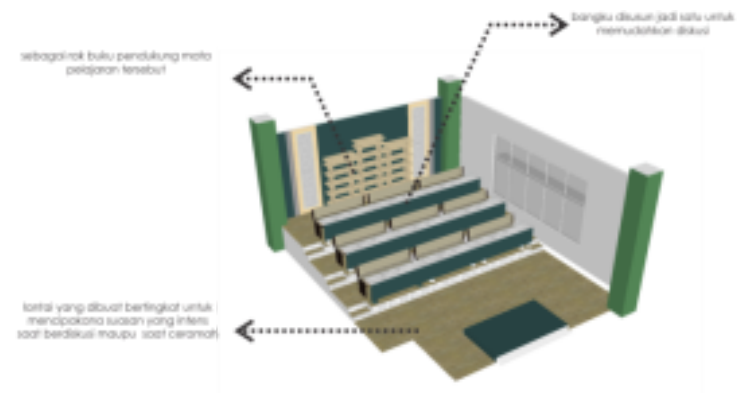

Gambar 5. Konsep Ruang Kelas Mata Pelajaran Ceramah Dan Diskusi

\section{- Mata Pelajaran Hafalan/ Cerita}

Yang terakhir yaitu mata pelajaran hafalan / cerita, pada kasus ini, mata pelajaran cenderung tidak terikat dengan ruang, ia bisa belajar dimanapun tempatnya, hal ini dikarenakan perilaku santriwati yang suka menghafal diluar kelas, serta pelajaran yang bersifat cerita cenderung tidak membutuhkan banyak properti, mata pelajaran bersifat cerita hanya perlu pemahaman pengajar yang baik untuk kemudian disampaikan kepada santriwati, agar ilmu tersebut disampaikan secara baik. mata pelajaran yang masuk dalam kategori ini diantaranya yaitu: mahfudzot, mutholaah, shorof, nisaiyyah dan conversation.

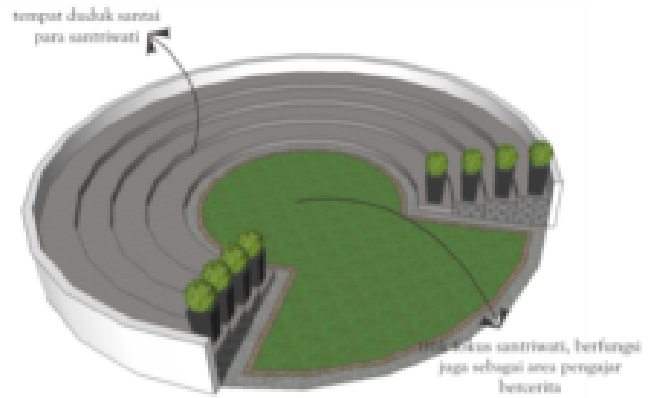

Gambar 6. Konsep Ruang Kelas Mata Pelajaran Hafalan dan Cerita

\section{- Ruang kelas prakarya}

Ruang kelas prakarya merupakan ruang kelas penunjang kegiatan ekonomi kreatif pondok, dimana pada kelas ini diisi dengan kegiatan santri dalam mengerjakan suatu kerajinan yang diambil dari limbah pertanian dan perkebunan kawasan untuk dijadikan suatu produk yang bernilai jual yang nantinya akan dipasarkan ke masyarakat, kegiatan dalam kelas ini berupa pertukaran ide, proses pengerjaan, dsb.

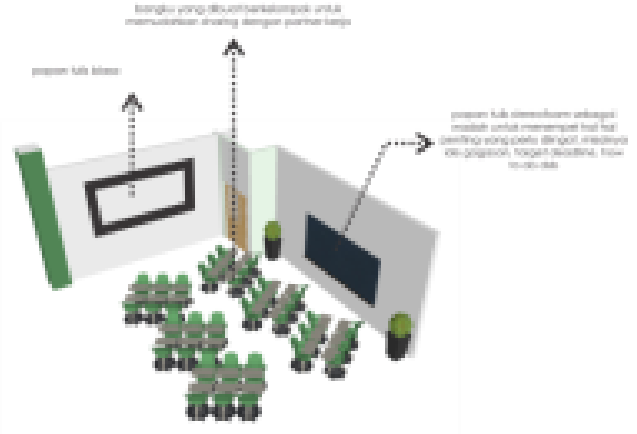

\section{Gambar 7. Konsep Ruang Kelas Prakarya}

\section{- Ruang kelas entrepreneur}

Ruang kelas entrepreneur juga merupakan ruang kelas penunjang kegiatan ekonomi kreatif pondok, yang mana pada 
kelas ini kegiatan santri diisi dengan pembelajaran tentang dunia wirausaha, ilmu ilmu tentang aspek ekonomi islam, sifat ruang kelas ini mengikuti bentukan dari ruang kelas diskusi yang mana bentuk ruang kelas dibuat berundak seperti ruang kelas mata pelajaran diskusi.

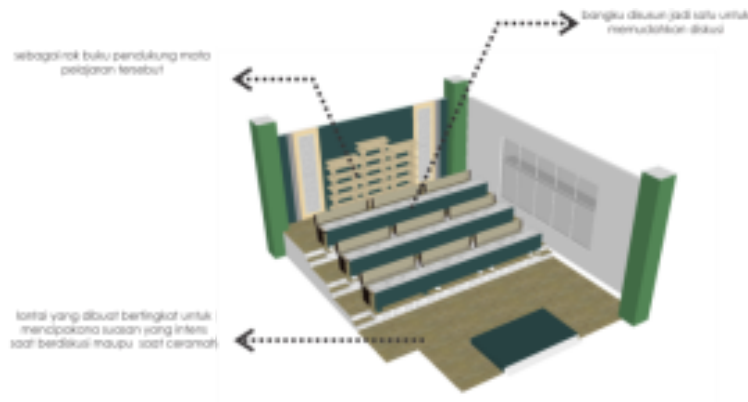

Gambar 8. Konsep Ruang Kelas Entrepreneur

\section{Konsep Asrama}

Konsep asrama pada Pondok Pesantren Darul Hijrah Putri ini mengadopsi dari konsep asrama sebelumnya yang mana banunan dijadikan 2 bagian dan dilengkapi oleh ruang komunal sebagai transisi dari 2 bangunan tersebut, selain itu untuk kamar asrama, kamar asrama dapat dihuni oleh 8-10 orang, hal ini dibuat agar meminimalisir banyaknya kamar yang nanti dibuat, selain itu banyaknya kamar yang dibuat akan berdampak dengan tidak edukatifnya kegiatan di asrama itu sendiri.

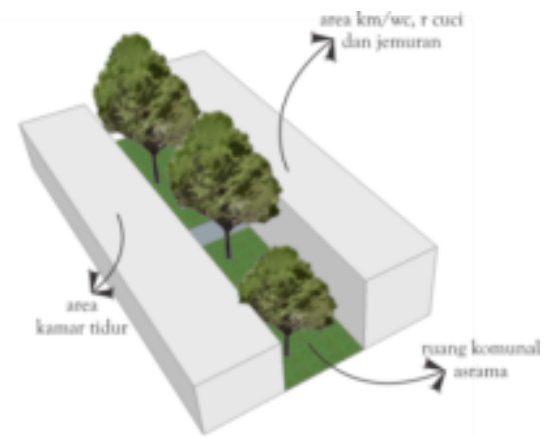

Gambar 9. Konsep Bangunan Asrama

\section{Konsep Ruang Pendukung Ekonomi Kreatif Pondok \\ - DH art gallery}

Merupakan display tempat penjualan hasil kerajinan santriwati untuk dijual ke khalayak ramai, tempat ini dijadikan satu dengan DH mart.

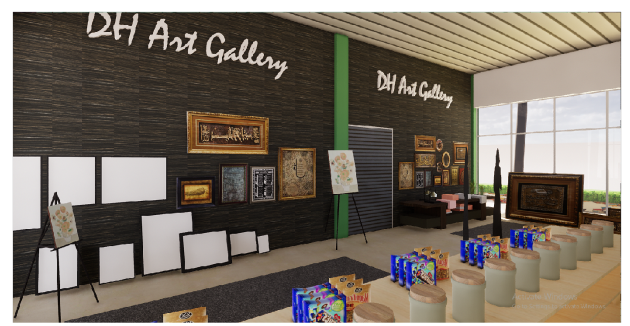

Gambar 10. Interior DH Art Gallery

\section{- DH mart}

Merupakan marketplace penjualan hasil panen pertanian dan perkebunan pondok yang dipasarkan kepada orang luar terlebih ke masyarakat sekitar, dan dengan adanya hal ini pula diharapkan $\mathrm{DH}$ mart dapat menjadi pasar kebutuhan sehari hari untuk masyarakat sekitar.

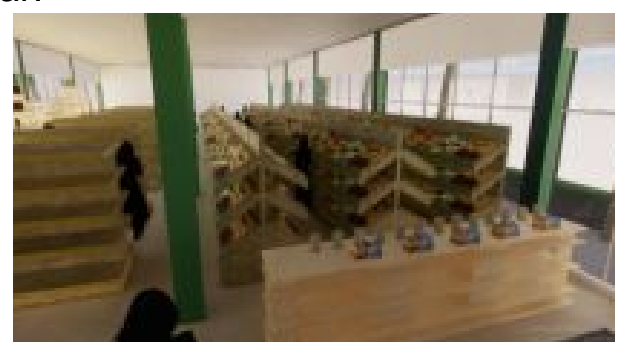

Gambar 11. Interior DH Mart

- DH Foodcourt

Merupakan area santai dengan dilengkapi kedai kedai minuman maupun makanan ringan untuk tamu santri maupun masyarakat sekitar, fungsi ini dikelola oleh asatidzah maupun santri pengurus pondok.

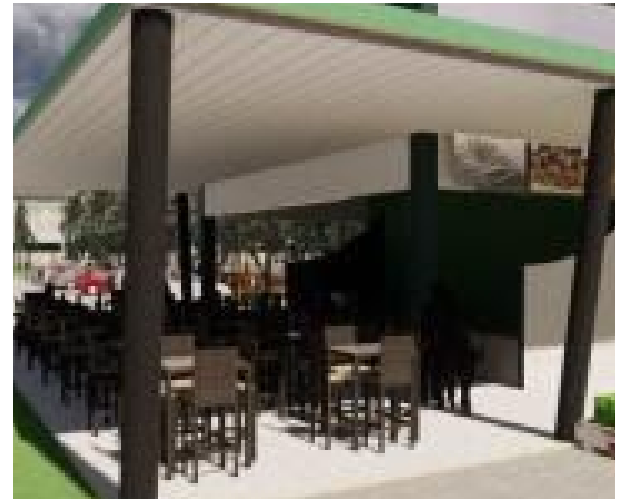

Gambar 12. DH Food Court

\section{PenerapaN Konsep Eksterior/ Landscape}

1. Konsep sirkulasi

Konsep sirkulasi kawasan dibuat dengan mengambil dasar dari 2 makna panca 
jiwa pondok yaitu pertama, panca jiwa kesederhanaan yang digambarkan dengan cara pembuatan sirkulasi yang memanjang mengikuti bentuk tapak hal ini dikarenakan diambil dari sifat sederhana serta pemilihan bentuk sirkulasi liner yang telah dianalisis pada tahap penulisan periode lalu. Kemudian yang kedua yaitu panca jiwa ukhuwah islamiyah digambarkan dengan sirkulasi yang menyambung satu sama lain tanpa terputus,dari awal sampai akhir.

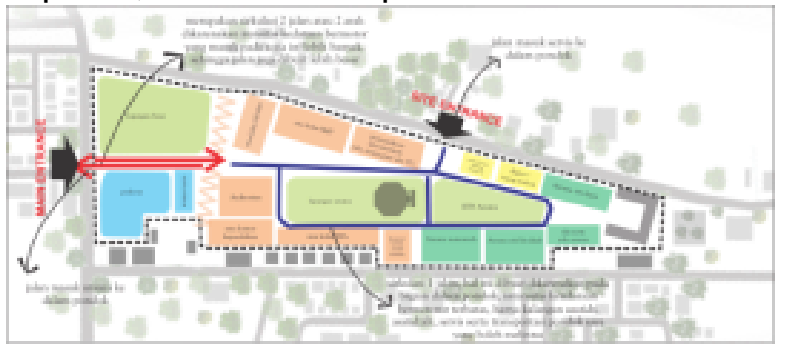

Gambar 13. Konsep Sirkulasi

\section{Konsep vegetasi}

Konsep vegetasi kawasan dibuat dengan cara menjadikan vegetasi sebagai barier kawasan alami yang dibuat mengelilingi area sekitar pondok, selain itu pada pemilihannya, vegetasi kawasan dipilih dengan pemilihan pohon pohon yang dapat menghasilkan buah, hal ini dibuat dikarenakan menyesuaikan dengan fungsi tambahan baru pada pondok pesantren yaitu ekonomi kreatif dalam bidang pertanian dan perkebunan, sehingga pemilihan pohon juga sangat berperan penting dalam penataan kawasan. Pada pemilihan pohon dalam kawasan, pohon pohon yang direncanakan merupakan pohon dengan buah buahan lokal.

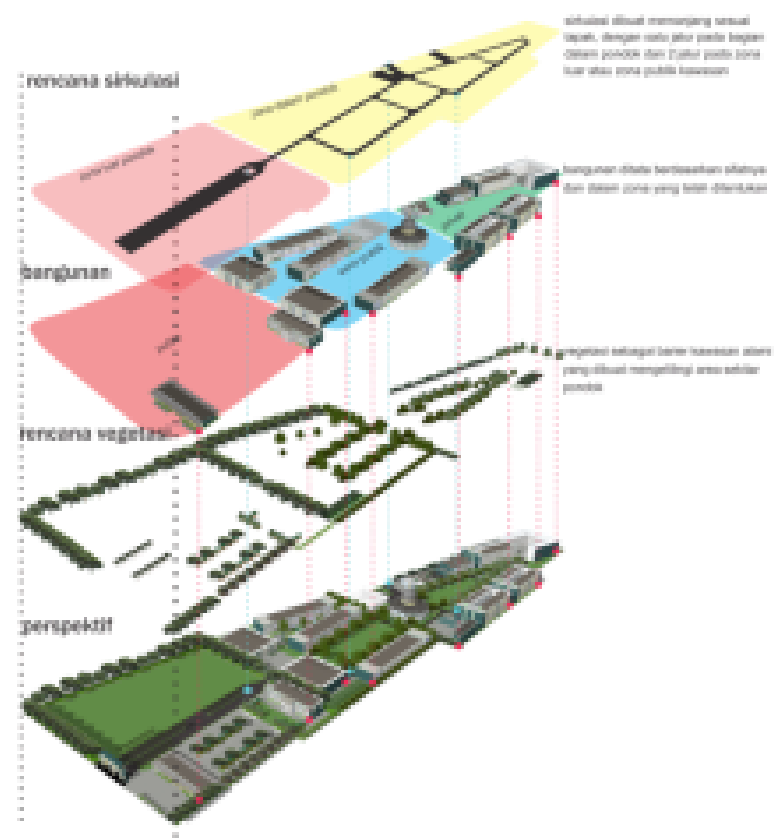

Gambar 14. Layer Rencana Vegetasi Terhadap Kawasan

\section{Konsep ruang luar}

Konsep ruang luar kawasan dibuat dengan memperhatikan kegiatan santri, baik kegiatan santri harian mingguan dan tahunan, selain itu kawasan juga diberikan fungsi baru lainnya berupa titik kebun, rumah hidroponik, serta taman. Untuk kebun diberikan di beberapa titik ruang kosong atau ruang kawasan yang berpotensi menjadi ruang mati apabila dibiarkan begitu saja. Untuk rumah hidroponik diletakkan didekat site entrance tempat masuk servis dikarenakan pada bagian tersebut kawasan merupakan kawasan yang lapang daripada yang lainnya, sehingga diharapkan cahaya matahari dapat masuk secara intens sedangkan untuk taman pondok difungsikan sebagai tempat santai dan juga sebagai tempat penghilang jenuh santri atas banyaknya kegiatan harian yang mereka lalui, taman dibuat dengan mengikuti konsep taman islami yang sering ditemui di timur tengah, yaitu dibuat dalam bentuk geometri, dengan tambahan elemen air dan bunga, selain konsep tersebut taman ini juga dibuat dengan penambahan tanaman peneduh berupa pohon berbuah sehingga selain sebagai taman ia juga tanpa langsung menjadi sebuah kebun 
buah yang dapat dipanen di beberapa kesempatan.

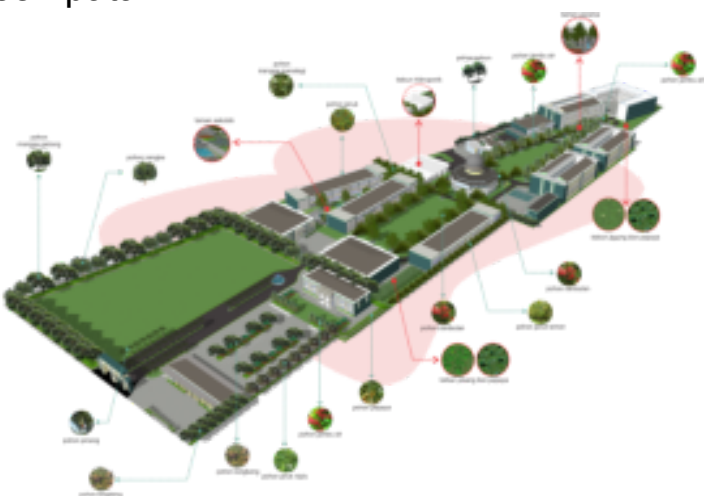

Gambar 15. Konsep Vegetasi Kawasan

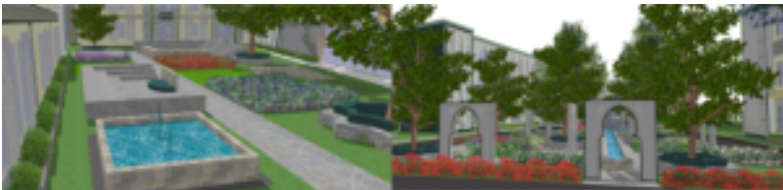

Gambar 16. Konsep Taman Kawasan

\section{E. Hasil Rancangan}

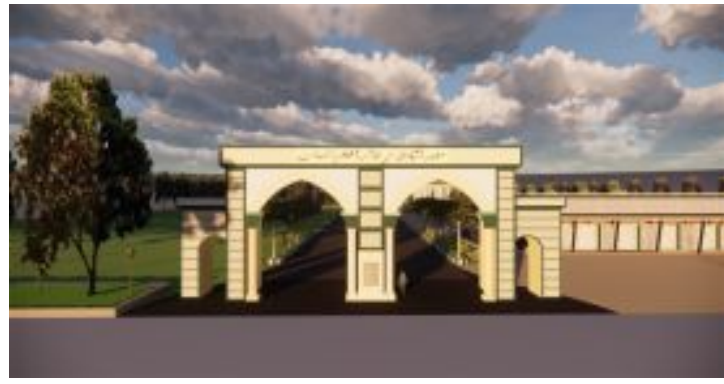

Gambar 17. gerbang utama

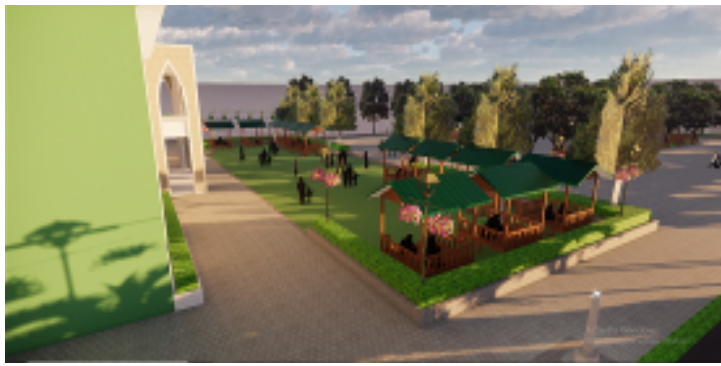

Gambar 18. RTH tamu

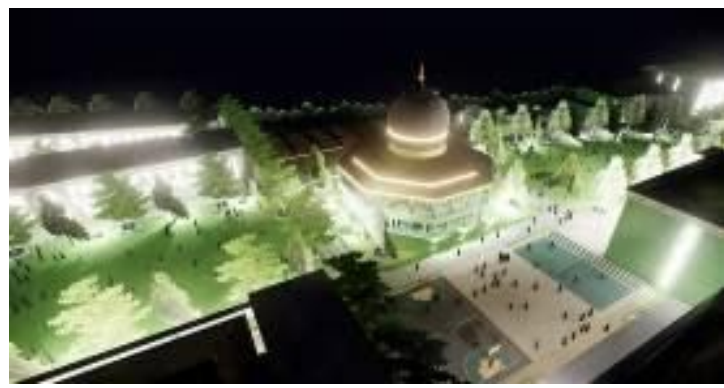

Gambar 19. Suasana malam

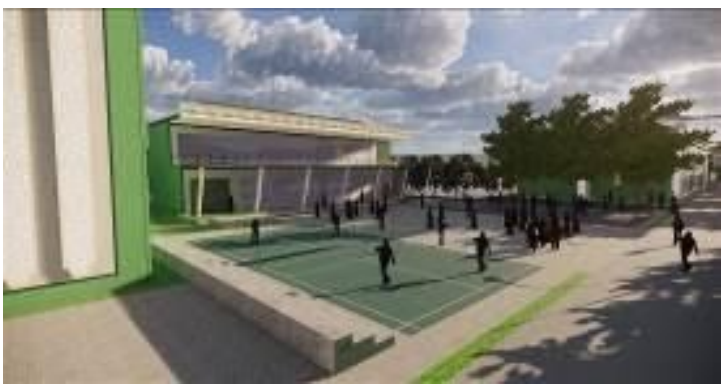

Gambar 20. Lapangan olahraga

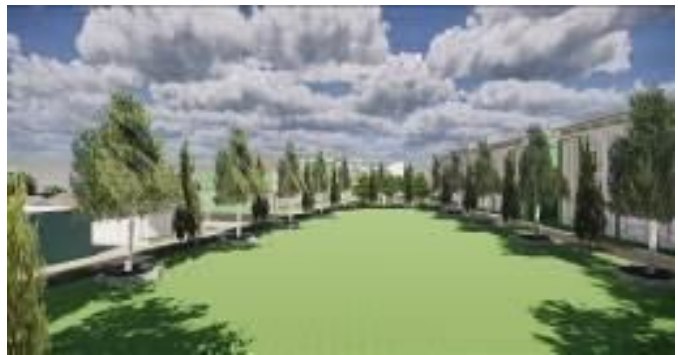

Gambar 21. Lapangan utama

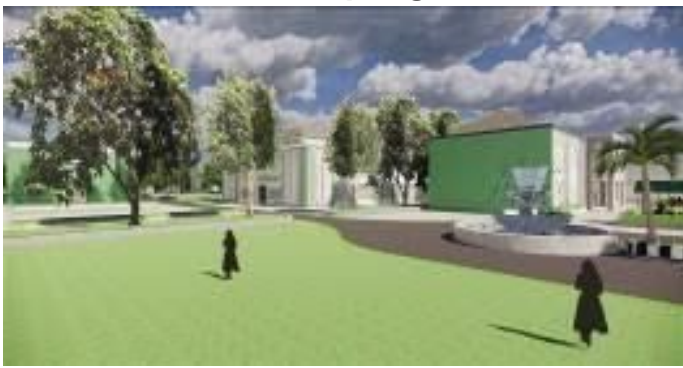

Gambar 22. Lapangan besar

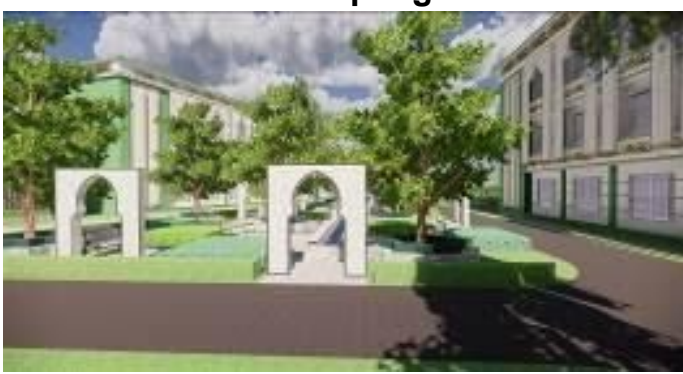

Gambar 23. Taman asrama

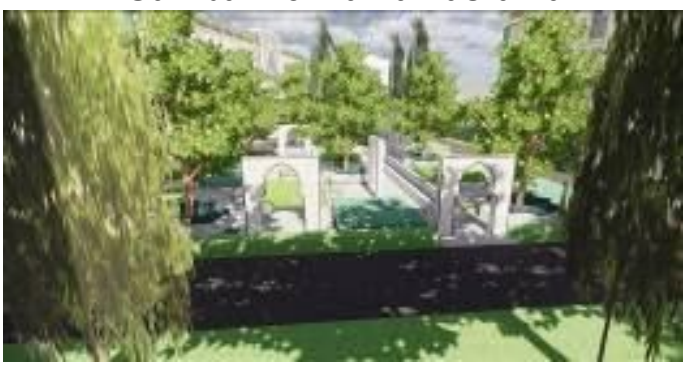

Gambar 24. Taman asrama 


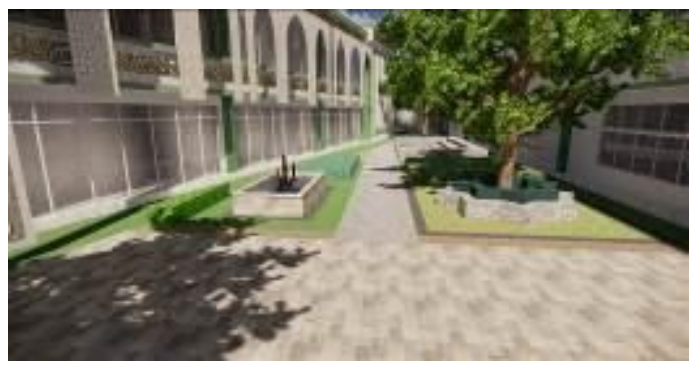

Gambar 25. Taman sekolah

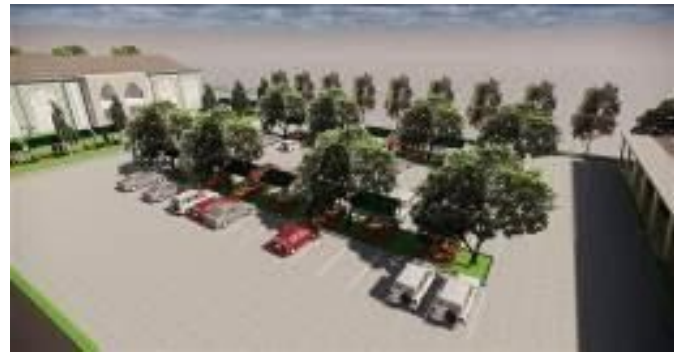

Gambar 26. Parkir tamu

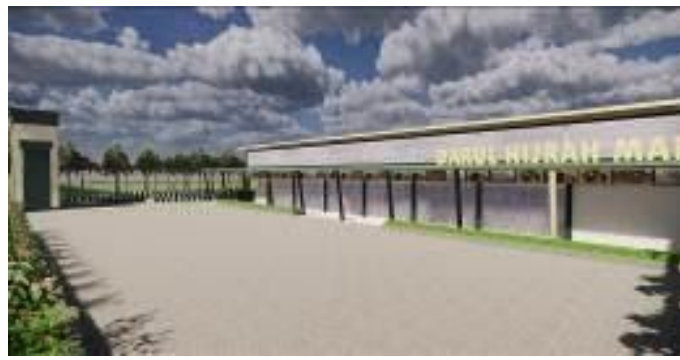

Gambar 27. Darul hijrah mart

KESIMPULAN

Kawasan Pondok Pesantren Darul Hijrah Putri diredesain dikarenakan membutuhkan pembaharuan dalam desain di masa depannya, melalui wawancara dan pengamatan di lapangan Pondok Pesantren ini penataan tata massa adalah rancangan yang sangat krusial yang perlu diperbaiki kembali dengan tambahan beberapa fasilitas baru seperti fasilitas pendukung dalam bidang ekonomi kreatif sebagai jawaban atas permasalahan yang diangkat sebelumnya dan sebagai kebutuhan pondok di masa yang akan datang.

Sesuai dengan analisa yang telah dilakukan sebelumnya maka perancangan kawasan baru untuk Pondok Pesantren Modern Darul Hijrah Putri dapat disimpulkan sebagai berikut:

1. Kawasan pondok dibagi menjadi 3 zona utama yaitu zona publik, semi publik dan privat. Didukung oleh Orientasi tata massa kawasan yang menggunakan konsep organisasi linear, hal ini dipakai karena mengikuti bentuk tapak yang memanjang, namun pada dasarnya kawasan tetap mempunyai titik pusat kawasan, yang mana titik pusat utama ditandai dengan masjid pondok.

2. Pencapaian ke dalam kawasan dapat diakses menggunakan 2 gerbang masuk, pertama gerbang masuk utama dan gerbang masuk servis dan sirkulasi dalam kawasan dibuat dengan menggunakan konsep sirkulasi tidak langsung

3. Penambahan fasilitas baru terutama dalam aspek ekonomi kreatif, hal ini didasari oleh rencana program pemerintah yang ingin meningkatkan kegiatan ekonomi kreatif di lingkungan ponpes, selain itu sarana ekonomi kreatif yang ditambahkan pada kawasan ini adalah sebagai sarana untuk kebutuhan pondok di masa yang akan datang

Dalam simpulan yang telah dijabarkan diatas, proyek redesain kawasan ini diharapkan dapat membuat lingkungan Pondok Pesantren Darul Hijrah Puteri menjadi lingkungan pendidikan yang harmonis sejahtera dan dan asri, selain itu dengan adanya peran ekonomi kreatif yang ditambahkan disana diharapkan juga dapat membuat lembaga pendidikan ini menjadi lebih profesional, berkesinambungan dan bermutu sesuai dengan visi misi Pondok Pesantren Darul Hijrah itu sendiri.

\section{DAFTAR PUSTAKA}

Ann, Syifa (2017). Kala Santri Menumbuhkan Potensi Ekonomi Kreatif Dari Pesantren. Diambil dari: https://www.kompasiana.com (diakses pada tanggal 02 Juni 2019)

Dhofier, Zamaksyari.1999. Tradisi Pesantren: Studi tentang Pandangan Hidup Kiyai. Jakarta: LP3ES.

DM, Herman. (2013). Sejarah Pesantren Di Indonesia. Kendari. Jurnal Al-Ta'dib, 6-2, 148-150.

Fadli, Adi. (2012). Pesantren:Sejarah dan Perkembangannya. Mataram: Jurnal 
El-Hikmah. Jurnal Pendidikan dan Kajian , V-1, 31-32.

Noviyanti, Ririn. (2017). Peran Ekonomi Kreatif Terhadap Pengembangan Jiwa Entrepreneurship di Lingkungan Pesantren. Malang: Jurnal Penelitian IImiah Intaj 1, Hal 81.

Suhartini, Euis. (2018). Ekonomi Kreatif Basis Pesantren. Diambil dari: http://banten.kemenag.go.id (diakses pada tanggal 03 Juni 2019).

Zainuddin. (2015). Pondok Pesantren Hidayatullah Taman Hudaya Di Martapura. Banjarbaru: Universitas Lambung Mangkurat 